\title{
One-pot sequential synthesis of tetrasubstituted thiophenes via sulfur ylide-like intermediates
}

\author{
Jun Ki Kim ${ }^{1,2}$, Hwan Jung Lim ${ }^{1}$, Kyung Chae Jeong ${ }^{*}$ and Seong Jun Park ${ }^{* 1}$
}

\author{
Full Research Paper \\ Address: \\ ${ }^{1}$ Research Center for Medicinal Chemistry, Korea Research Institute \\ of Chemical Technology (KRICT), 141 Gajeong-ro, Yuseong-gu, \\ Daejeon 34114, Korea, ${ }^{2}$ Department of Chemistry, Chungnam \\ National University, 99 Daehak-ro, Yuseong-gu, Daejeon 34134, \\ Korea and ${ }^{3}$ Translational Research Branch, National Cancer Center, \\ 323 Ilsan-ro, Ilsandong-gu, Goyang-si Gyeonggi-do 10408, Korea

\section{Email:} \\ Kyung Chae Jeong* - jeongkc@ncc.re.kr; Seong Jun Park* - \\ sjunpark@krict.re.kr \\ * Corresponding author \\ Keywords: \\ 5-(heterocyclic)thiophenes; one-pot sequential synthesis; sulfur ylide; \\ tetrasubstituted thiophene
}

Beilstein J. Org. Chem. 2018, 14, 243-252.

doi:10.3762/bjoc.14.16

Received: 08 November 2017

Accepted: 10 January 2018

Published: 26 January 2018

Associate Editor: D. Y.-K. Chen

(c) 2018 Kim et al.; licensee Beilstein-Institut. License and terms: see end of document.

\begin{abstract}
Herein, we describe a novel approach for the practical synthesis of tetrasubstituted thiophenes $\mathbf{8}$. The developed method was particularly used for the facile preparation of thienyl heterocycles $\mathbf{8}$. The mechanism for this reaction is based on the formation of a sulfur ylide-like intermediate. It was clearly suggested by (i) the intramolecular cyclization of ketene $N, S$-acetals 7 to the corresponding thiophenes 8, (ii) ${ }^{1} \mathrm{H}$ NMR studies of Meldrum's acid-substituted aminothioacetals 9, and (iii) substitution studies of the methoxy group on Meldrum's acid containing $N, S$-acetals $\mathbf{9 b}$. Notably, in terms of structural effects on the reactivity and stability of sulfur ylide-like intermediates, 2-pyridyl substituted compound 7a exhibited superior properties over those of others.
\end{abstract}

\section{Introduction}

Since the discovery of stable sulfonium ylides 1 in 1930 [1] and the pioneering work of several research groups during the $1960 \mathrm{~s}$ (2 and 3) [2-9], these carbene precursors have been played an important role in organic chemistry [10-22]. As shown in Figure 1, sulfur(IV) and sulfur(VI) ylides are stable. The stability of sulfonium ylides is determined by the electron delocalization of the carbanionic center and the substituents on the sulfur atom [10]. In general, these reagents are often applied in the preparation of simple small rings [13], such as epoxides [1418], cyclopropanes [19-22], aziridines [23], indoles [24], pyrroles [24], and indolines [25]. In addition, other reactions involving sulfonium and sulfoxonium ylides have been reported recently [26-32]. For example, Shen and co-workers reported the use of trifluoromethyl-substituted sulfonium ylide $\mathbf{5}$ in elec- 
trophilic trifluoromethylation reactions [33,34]. Moreover, Maulide and co-workers reported an effective ylide transfer reagent, which led to sulfonium ylide 6 [35-38].

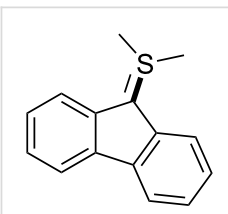

1

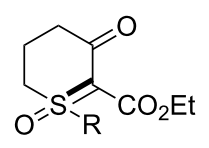

4

$$
\underset{\substack{\text { III } \\ \text { II }}}{\text { I }} n=0,1
$$

2

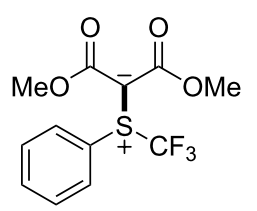

5

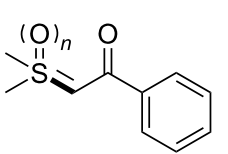

3

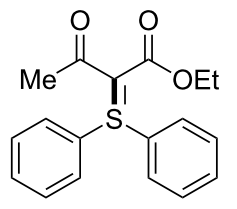

6
Figure 1: The selected examples of sulfur(IV) and sulfur(VI) ylides 1 [1], 2 [5-7], 3 [6,7,9], 4 [11,12], 5 [33,34], 6 [35-38].

As part of our ongoing efforts to discover small molecule modulators of protein-protein interactions (PPIs), we are particularly interested in coplanar compounds that mimic $\beta$-strand side-chain distributions [39-43]. Consequently, we are fascinated with thienyl-pyridyl ring systems [43] and have explored facile synthetic procedures to facilitate their production. For the synthesis of heterocyclic-heterocyclic biaryl compounds, numerous studies have been carried out to develop efficient catalytic methods [44-49]. In general, Pd-catalyzed Suzuki-Miyaura cross-coupling reactions are the most popular synthetic strategy for aryl-aryl bond-forming reactions [50-52]. However, it has been reported that the Suzuki cross-coupling of nitrogen- and sulfur-containing heterocycles is more challenging than those of aryl-aryl derivatives. These difficulties resulted from the special properties of thiopheneboronic acids - the sensitivity to polar reaction media and easy degradation by protodeboronation [53].

As a recent example of a metal-free synthesis of the targeted thienylpyridines (Figure 2A and 2B), Al-Showiman and co-workers reported a trisubstituted 5-(pyridin-2-yl)thiophene, obtained from the reaction of 5-(enaminone)thiophene with 2,4pentanedione in glacial acetic acid in the presence of ammonium acetate $[54,55]$. Ila and co-workers reported the synthesis of tri- and tetrasubstituted thiophenes via the intramolecular cyclization of $S$-alkylated heterocyclic-aryl dithioesters [56]. However, these approaches are limited by the multistep synthesis (Figure 2A) [54,55] and the complicated dithioester preparation (Figure 2B) [56]. In general, tetrasubstituted thiophenes have primarily been prepared by base-catalyzed intramolecular Dieckmann-, Thorpe-Ziegler, and aldol-type condensations of the corresponding ketene- $N, S$-acetals [57-67]. These methods are still need strong bases [60], high temperatures [62,64,65], and are generally low yielding [57,62]. Thus, a new mild synthetic route for the synthesis of 5-(pyridyl)thiophenes is required. We therefore investigated the synthesis of thienylpyridines using a metal-free approach.

\section{Results and Discussion}

At first, our efforts focused on the intramolecular cyclization reactions with mild conditions - in the absence of an added base at room temperature. To obtain aminothioacetal $\mathbf{7 a}$, we initially performed the $S$-alkylation of the intermediate thiolate salt with 2-(bromomethyl)pyridine at room temperature overnight. We interestingly found that the desired 5-(pyridin-2-yl)thiophenes 8a has already been achieved by the intramolecular aldol-type condensation of $N, S$-acetal 7a (Figure 2C). Subsequently, we investigated the scope of the reaction using our optimized conditions (Scheme 1).

As shown in Scheme 1, various isothiocyanates containing aryl and alkyl groups were applied, and the desired thiophenes (8aa-ai) were obtained in moderate to excellent yields (47-92\%). When different 1,3-diketones were applied, the yields were affected by the keto-enol tautomer ratio. Alkyl substituents (isopropyl and cyclopropyl), which promote the enol forms of the ketones, afforded thiophenes 8aj and 8ak in good to excellent yields $\left(68 \%\right.$ and $81 \%$ ). However, a $\mathrm{CF}_{3}$ substituent, which is electron-withdrawing and might promote the keto form, provided the desired compound 8al in a low yield (14\%). When the enolate was derived from 3-oxo-3-phenylpropanenitrile, 3-cyano-4-phenylthiophene 8am was obtained in a low yield (32\%). Starting from malonitrile, compound 8an was also prepared in a moderate yield (50\%) via a Thorpe-Ziegler-type cyclization of $N, S$-acetal $7 \mathbf{a n}$. In this case, the intramolecular cyclization reaction was carried out at $100{ }^{\circ} \mathrm{C}$ for $3 \mathrm{~h}$. With 5,5dimethylcyclohexane-1,3-dione, thiophene 8ao was obtained in a low yield (25\%). X-ray crystal structures of thiophenes $\mathbf{8 a d}$ and 8an are illustrated in Figure 3 [68].

Mechanistically, our experimental findings may be attributed to the formation of sulfur ylide-like intermediates. To support this reaction pathway, further studies were performed. By changing the substituent groups on $N, S$-acetals 7 , the effects of the structure on the stability and the reactivity of the intermediates were investigated (Table 1).

In terms of inductive and mesomeric effects, we postulated that the electron rich pyridyl $\mathrm{N}$ atom could carry a negative charge at the picolinyl position (Table 1, entries 1 to 5). Interestingly, the 2-pyridyl moiety provided stable and reactive $N, S$-acetal $7 \mathbf{a a}$, which could be isolated and afforded the desired thio- 
A) 5-(pyridin-2-yl)thiophenes as potential antimicrobial agents<smiles>CCCCC(=O)c1sc(Nc2ccccc2)c(C(=O)OCC)c1C</smiles><smiles>CCOC(=O)c1c(Nc2ccccc2)sc(C(=O)/C=C/N(C)C)c1C</smiles>
multistep synthesis<smiles>CCOC(=O)c1c(Nc2ccccc2)sc(C(=O)CC(N)C(C(C)=O)C(=O)CC)c1C</smiles><smiles>CCCCCCCC</smiles><smiles></smiles>

B) lla's one-pot synthesis

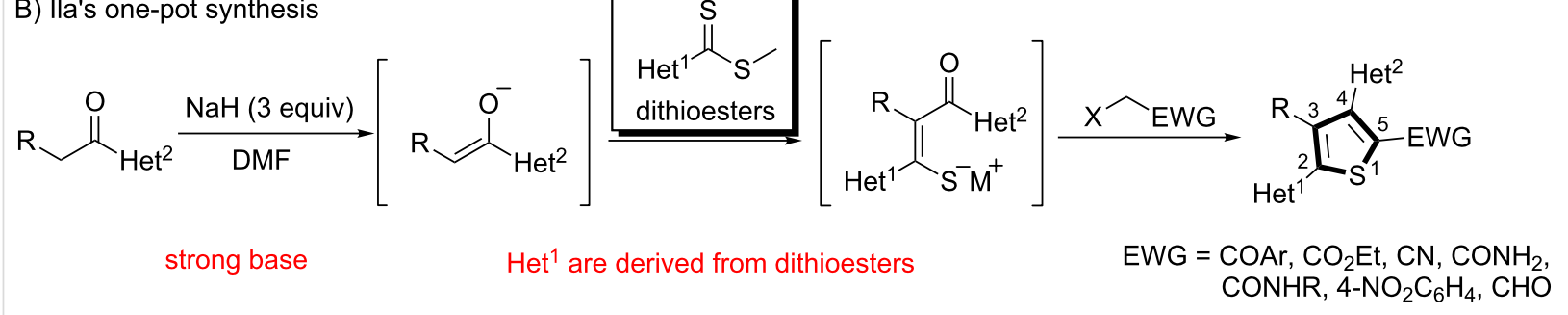

C) this approach: in situ formation of the sulfur ylide-like intermediate

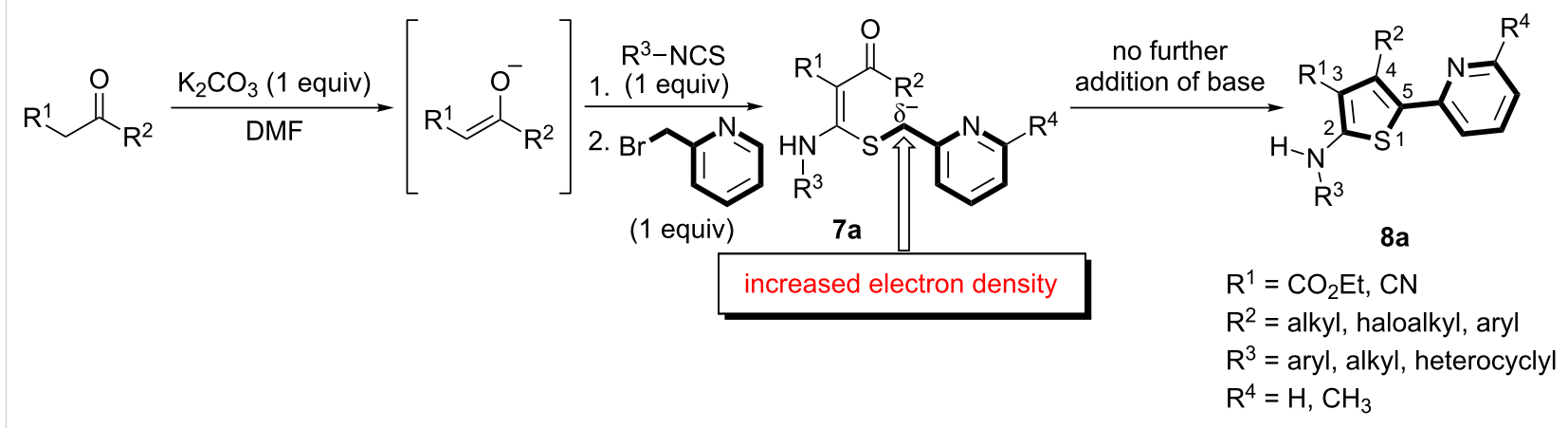

Figure 2: Metal-free synthesis of thiophene-based heterocycles $(A)[54,55],(B)[56]$.

phene 8aa in an excellent yield (92\%, Table 1, entry 1). The substrate containing a 3-pyridyl group only afforded $S$-alkylated compound $\mathbf{7 b}$, while 4-pyridyl substituted intermediate $\mathbf{7 c}$ could be easily transformed into thiophene $8 \mathbf{c}$ at $0{ }^{\circ} \mathrm{C}$ (Table 1 , entries 2 and 3). Notably, the special properties associated with the 2- and 4-positions of pyridine [69-72] are evident in this study. In the case of 6-methylpyridine-substituted $N, S$-acetal 7d, the formation of a resonance stabilized enaminate anion had a smaller contribution and this resulted in a reduced yield (34\%, Table 1, entry 4) [70]. To identify the effects of sulfur, a reaction with the corresponding isocyanate was performed to introduce an oxygen atom. As a result, only $O$-alkylation compound 7e was obtained instead of the desired furan (Table 1, entry 5). It is possible to consider that the d orbitals of the sulfur atom in a sulfide group could possibly stabilize the adjacent carbanion $[73,74]$.
To expand the scope of substituted $N, S$-acetals that could provide the desired sulfur ylide-like intermediates, various heterocycles were subjected to the reaction (Table 1, entries 6-11). The desired thiophenes $\mathbf{8 f}$ and $\mathbf{8 g}$ were obtained in low yields from the respective furans $(33 \%$ and $20 \%$, Table 1 , entries 6 and 7). With thiophene, however, only $N, S$-acetal compound $7 \mathbf{h}$ was obtained. Thiophene could not generate the desired intermediate because of the lower electronegativity and a weaker inductive effect of sulfur (Table 1, entry 8). Among 1,2,4-oxadiazole moieties, the 3-trifluoromethyloxadiazole group afforded the desired thiophene 8i (Table 1, entry 9), whereas the 5-trifluoromethyloxadiazole substituent was not a viable substrate (Table 1, entry 10). Because of a similar result obtained with the $N$-methylimidazole substituted compound $7 \mathbf{k}$, the difference between $7 \mathbf{i}$ and $7 \mathbf{j}$ could be explained by the imidazole-like structure of the 5-trifluoromethyloxadiazole 


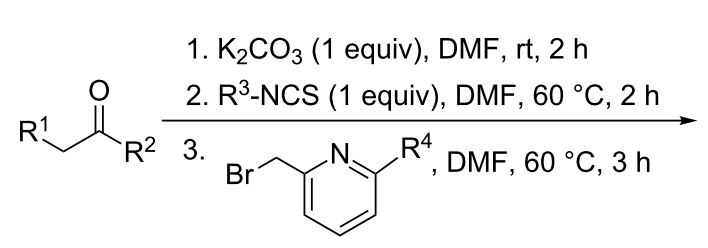

(1 equiv)

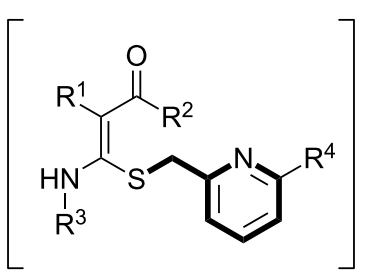

$7 a$<smiles>[R]Nc1sc(-c2ccccn2)c(C)c1C(=O)OCC</smiles>

8ag: $R^{3}=\mathrm{CH}_{3}(82 \%)$

8ah: $R^{3}=$ cyclohexyl $(57 \%)$

8ai: $R^{3}=$ benzyl $(61 \%)$

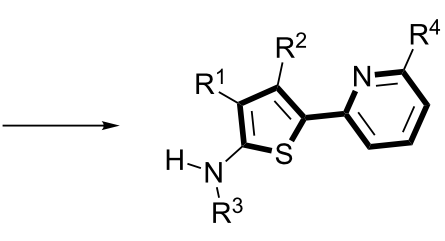

$8 a$

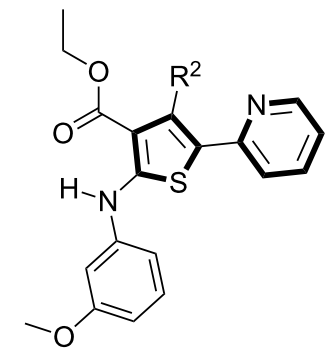

8aj: $R^{2}=$ isopropyl $(68 \%)$

8ak: $R^{2}=$ cyclopropyl $(81 \%)$

8al: $\mathrm{R}^{2}=\mathrm{CF}_{3}(14 \%)$

8ac: $R^{3}=4-B r-P h, R^{4}=H(71 \%)$

8ad: $\mathrm{R}^{3}=2-\mathrm{Br}-5-\mathrm{Cl}-\mathrm{Ph}, \mathrm{R}^{4}=\mathrm{CH}_{3}(47 \%)$

8ae: $R^{3}=3-\mathrm{CF}_{3}-\mathrm{Ph}, \mathrm{R}^{4}=\mathrm{H}(82 \%)$

8af: $\mathrm{R}^{3}=4-\mathrm{NO}_{2}-\mathrm{Ph}, \mathrm{R}^{4}=\mathrm{H}(73 \%)$

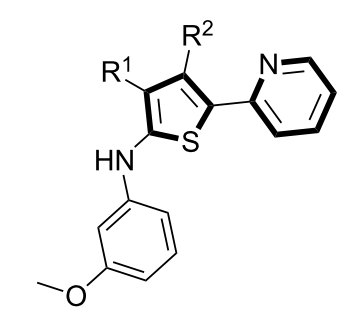

8am: $\mathrm{R}^{1}=\mathrm{CN}, \mathrm{R}^{2}=\mathrm{Ph}(32 \%)$

8an: $R^{1}=C N, R^{2}=N_{2}(50 \%)^{a}$

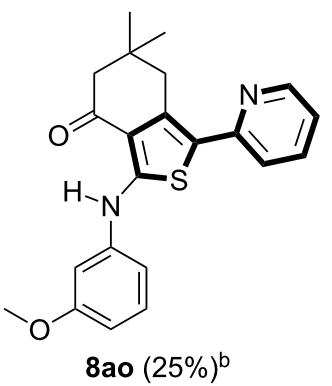

Scheme 1: One-pot sequential synthesis of the trisubstituted 5-(pyridine-2-yl)thiophenes $8 \mathbf{a}$. Substrate: ${ }^{a}$ malonitrile; ${ }^{b} 5,5-d i m e t h y l c y c l o h e x a n e-1,3-$ dione.

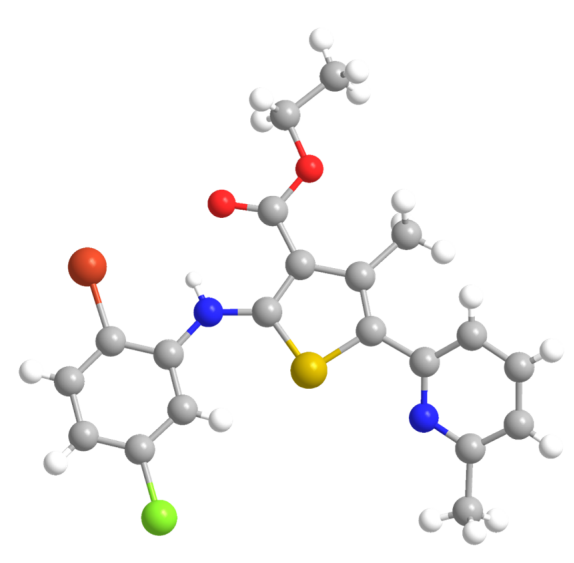

8ad

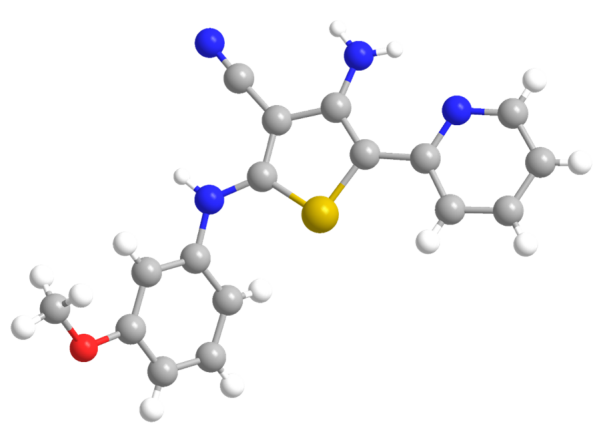

8an

Figure 3: X-ray crystal structures of 8ad and 8an [68]. 
Table 1: Examination of $N, S$-acetals substituted with a heterocycle (7aa-k) or an arene (7I-p).

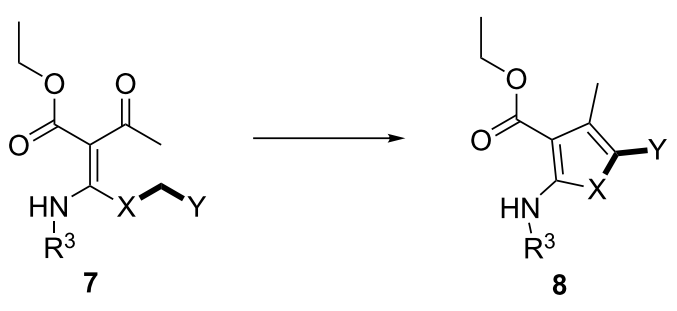

\begin{tabular}{|c|c|c|c|c|c|}
\hline Entry & Substrates & $x$ & $Y$ & Products & Yield $(\%)^{a, b}$ \\
\hline 1 & 7 aa & $\mathrm{s}$ & & $8 \mathbf{a a}$ & 92 \\
\hline 2 & $7 b$ & $s$ & & $8 b$ & $-^{c}$ \\
\hline $3^{d}$ & $7 c$ & $s$ & & $8 c$ & 80 \\
\hline 4 & $7 d$ & $s$ & & $8 d$ & 34 \\
\hline 5 & $7 e$ & $\mathrm{O}$ & & $8 e$ & $-^{c}$ \\
\hline 6 & $7 f$ & $\mathrm{~s}$ & & $8 f$ & 33 \\
\hline 7 & $7 g$ & $s$ & & $8 g$ & 20 \\
\hline 8 & $7 \mathrm{~h}$ & s & & $8 \mathrm{~h}$ & $-^{c}$ \\
\hline 9 & $7 \mathrm{i}$ & s & & $8 i$ & 47 \\
\hline 10 & $7 \mathrm{j}$ & $s$ & & 8j & $-^{c}$ \\
\hline 11 & $7 k$ & $\mathrm{~s}$ & & $8 k$ & 8 \\
\hline 12 & 71 & $S$ & & 81 & $-^{\mathrm{c}}$ \\
\hline 13 & $7 m$ & s & & $8 m$ & $-^{c}$ \\
\hline
\end{tabular}


Table 1: Examination of $N, S$-acetals substituted with a heterocycle (7aa-k) or an arene (71-p). (continued)

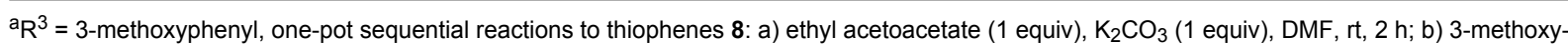
phenyl isothiocyanate (1 equiv), DMF, $60^{\circ} \mathrm{C}, 2 \mathrm{~h}$; c) the corresponding halomethylarenes or halomethyl heterocycles ( 1 equiv), DMF, $60{ }^{\circ} \mathrm{C}, 3 \mathrm{~h}$; ${ }^{b}$ After column chromatography; ${ }^{c}$ no desired reaction; d decause $\mathrm{N}, \mathrm{S}$-acetal $7 \mathrm{c}$ readily transfer to the corresponding thiophene $8 \mathrm{c}$ at $0{ }^{\circ} \mathrm{C}$, the substrate $7 \mathrm{c}$ could not be isolated.

moiety. The reduced inductive effect of the amine might be attributed to the resonance structures of imidazole (Table 1, entry 11) [72].

To determine the influence of substituents on the phenyl group, various arene(methyl)sulfanes $\mathbf{7 1 - p}$ were tested (Table 1, entries 12-16,). Simple phenyl and electron-donating compounds $7 \mathbf{l}$ and $\mathbf{7 m}$ did not provide the desired thiophenes 81 and $\mathbf{8 m}$. Although electron-withdrawing groups such as $\mathrm{CN}$ and $\mathrm{SF}_{5}$ did not show any effect (Table 1 , entries 14 and 15), $\mathrm{NO}_{2}$, the strongest electron-withdrawing group [75-77], provided the desired thiophene $8 \mathbf{p}$ in a moderate yield (42\%).

While further studies are required, we suggest the sulfur ylidelike intermediates $\mathbf{7 a a}, \mathbf{7} \mathbf{c}, \mathbf{7 p}, \mathbf{7 i}$, and $\mathbf{7 f}, \mathbf{g}$ after considering the literature [69-72] and McNab's research on the synthesis of 3-hydroxythiophene and thiphene-3(2H)-ones (Figure 4) [78]. With regards to McNab's work, the dipolar species $\left[\mathrm{R}_{2} \mathrm{C}=\mathrm{S}^{+}-\mathrm{CH}^{-}-\mathrm{R}^{\prime}\right]$ were proposed as reaction intermediates [78]. In our studies, it was shown that the order of reactivity was $7 \mathbf{c} \geq 7 \mathbf{a a}>\mathbf{7 i}, \mathbf{7} \mathbf{p} \geq \mathbf{7 f}, \mathbf{7 g}$. The different reactivities of the intermediates were related to the presence of heteroatoms, particularly their inductive and mesomeric effects [69-72]. For example, 2-pyridyl-substituted ylide-like intermediate 7aa showed the desired properties in terms of both reactivity and stability, whereas the 4-pyridyl group only displayed high reactivity. For alkylpyridines $\mathbf{7 a a}$ and $\mathbf{7 c}$, our observations may be explained by Fraser's measurements of the $\mathrm{pKa}$ values $[69,70,79]$ : among isomeric benzylpyridines, the 4-isomer is more acidic than the 2-isomer, and the 4- and 2-isomers are much more acidic than the 3 -isomer. In the case of the oxadiazole-substituted compound $7 \mathbf{i}$, inductive and mesomeric effects facilitated its sulfur ylide-like intermediate formation [71]. For compounds $\mathbf{7 f}$ and $7 \mathrm{~g}$, the low reactivity resulted from the decreased mesomeric effect of the furan structure: the higher electronegativity of oxygen facilitated the polarized form [71]. Among various arenes, the 4-nitrophenyl substituent $7 \mathbf{p}$ only afforded the desired thiophene $\mathbf{8 p}$ in a moderated yield (42\%) and, the favorable resonance form is illustrated in Figure 4.

According to the recent reports on the multiple isomeric structures of ketene $N, S$-acetals [80-83], structural assignments of the ketene $N, S$-aminothioacetals 7 by ${ }^{1} \mathrm{H}$ NMR are not facile. To overcome these difficulties, we prepared $N, S$-acetals $9 \mathbf{a}-\mathbf{c}$ since the X-ray crystal structure of Meldrum's acid-based $N, S$ acetal was reported by Wentrup [84]. In addition, the intramolecular aldol condensation of Meldrum's acids did not occur due to the ketone structures. Table 2 displays the ${ }^{1} \mathrm{H}$ NMR result of the sulfur ylide-like intermediate $\mathbf{9 b}$, and demonstrates the effect of increasing electronegativity on the $\mathrm{CH}_{2}$ proton.<smiles>CCC(C)=[S+]CC1C=CC=CN1</smiles>

$7 a a$<smiles>CC(C)=[S+]C[C]1C=C[N-]C=C1</smiles>

7c<smiles>CC(C)=[S+]C[C]1C=CC(=[N+]([O-])[O-])C=C1</smiles>

$7 p$<smiles>CCC(C)=[S+]CCc1nc(C(F)(F)F)no1</smiles>

$7 \mathbf{i}$<smiles>[R]c1ccc(C[SH]=C(C)C(C)C)o1</smiles>

7f: $\mathrm{R}=\mathrm{NO}_{2}$

$7 \mathrm{~g}: \mathrm{R}=\mathrm{CO}_{2} \mathrm{Me}$

Figure 4: The proposed structure of sulfur ylide-like intermediates; resonance contributors (mesomeric structures) [69-72,78]. 
Table 2: ${ }^{1} \mathrm{H}$ NMR studies of Meldrum's acid-based $N, S$-acetals $9 \mathrm{a}-\mathrm{c}^{\mathrm{a}, \mathrm{b}}[84]$.<smiles></smiles>

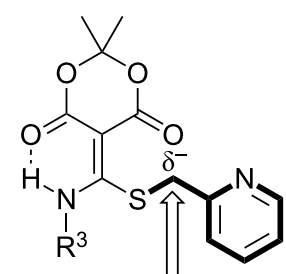

$\mathrm{Y}=$ phenyl, 3-pyridyl

9a, 9c

increased electron density

$9 b$

\begin{tabular}{|c|c|c|c|}
\hline Entry & $N, S$-Acetals ${ }^{c, d}$ & Structure & $-\mathrm{SCH}_{2} \mathrm{Y}^{1} \mathrm{H} \mathrm{NMR}(\mathrm{ppm})^{\mathrm{e}}$ \\
\hline 1 & $9 a$ & & 4.02 \\
\hline 2 & $9 b$ & & 4.15 \\
\hline 3 & $9 c$ & & 4.01 \\
\hline
\end{tabular}

${ }^{\mathrm{a}} \mathrm{R}^{3}=3$-methoxyphenyl; ${ }^{\mathrm{b}} \mathrm{S}$-alkylation of the thiolate with 4-(bromomethyl)pyridine hydrobromide was not successful; ${ }^{\mathrm{c}}$ one-pot sequential reactions to $\mathrm{N}, \mathrm{S}$-acetals 9: a) Meldrum's acid (1 equiv), $\mathrm{K}_{2} \mathrm{CO}_{3}$ (1 equiv), DMF, rt, $2 \mathrm{~h}$; b) 3-methoxyphenyl isothiocyanate (1 equiv), DMF, $60{ }^{\circ} \mathrm{C}, 2 \mathrm{~h}$; c) the corre-

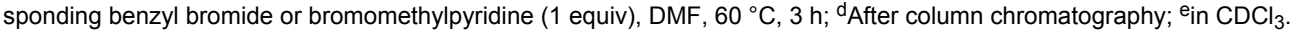

The 2-pyridyl group caused a downfield shift of 0.13 to $0.14 \mathrm{ppm}$ compared to phenyl and 3-pyridyl groups (Table 2, entry 2).

Further ${ }^{1} \mathrm{H}$ NMR studies of pyridin-2-ylmalononitrile 7an, pyridine-2-ylmethyl methanimidothioate 7ao, and time dependent experiments of the intramolecular aldol condensation of $N, S$ acetal $7 \mathbf{a a}$ to $8 \mathbf{a a}$ in $N, N$-dimethylformamide- $d_{7}$ at room temperature confirmed the formation of the stable sulfur ylide-like intermediates, thus indicating the successful transformation into thiophenes 8an, 8ao, and 8a (see Supporting Information File 1).

In addition to the spectroscopic studies, we attempted to gain additional evidence to support the formation of sulfur ylide-like intermediates via another approach. We selected stable Meldrum's acid containing $N, S$-acetals $9 \mathbf{a}$ and $\mathbf{9 b}$ for further investigation. Based on previous reports regarding carbene generation from sulfonium ylides $[6,85,86]$, compounds $\mathbf{9 a}$ and $\mathbf{9 b}$ were reacted with excess $\mathrm{MeOH}$ (Scheme 2). Interestingly, 2-pyridyl-substituted $\mathrm{N}, \mathrm{S}$-acetal $\mathbf{9 b}$ only provided $\mathrm{N}, \mathrm{O}$-acetal 9ba via a 1,4-Micheal addition, whereas $N, S$-acetal 9a was completely recovered after the reaction. We believed that these results support the existence of sulfur ylide-like intermediates (Scheme 2) [87].<smiles>[R]NC(SCc1ccccc1)=C1C(=O)OC(C)(C)OC1=O</smiles>

9a<smiles></smiles>

$9 b$

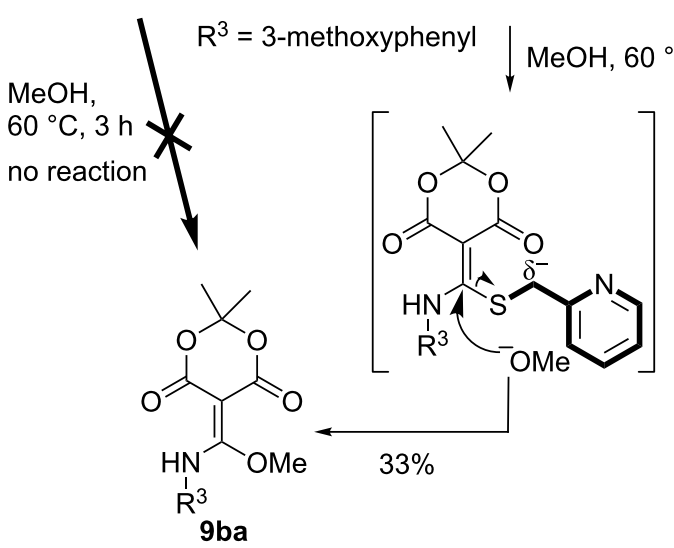

$30 \%$ of $9 \mathbf{b}$ was recovered

Scheme 2: The substitution reaction with $\mathrm{MeOH}$. 


\section{Conclusion}

In conclusion, we have developed a new synthetic pathway for the preparation of 2-amino-5-(heterocyclic)thiophenes $\mathbf{8}$. We have also shown that sulfur ylide-like intermediates 7 , which are easily converted into the desired thiophenes $\mathbf{8}$, can be generated in situ by $S$-alkylation of the intermediate thiolate salts. By ${ }^{1} \mathrm{H}$ NMR analysis of $N, S$-acetals 9 and methoxy group substitution of $\mathbf{9 b}$, the formation of sulfur ylide-like intermediates was successfully demonstrated. The transformation of ylide-like intermediates into the corresponding thiophenes was affected by their electronic properties. Among the various tested residues, the 2-pyridyl motif provided the desired reactivity and stability. This approach could be considered a powerful strategy for the preparation of biologically important thienyl heterocycles. Subsequent studies shall focus on applying this chemistry in other reactions that require sulfur ylides, and the biological activities of thiophenes $\mathbf{8}$ will also be reported in due course.

\section{Supporting Information}

\section{Supporting Information File 1}

Experimental part.

[https://www.beilstein-journals.org/bjoc/content/

supplementary/1860-5397-14-16-S1.pdf]

\section{Acknowledgements}

This work was fully supported by the KRICT/NCC action project (IKT1606-H02, IKT1706H02, KK1807-C51, and SKO1807C5). The authors thank Dr. Chong-Hyeak Kim and Yoon Mi Choi for X-ray analyses. Also, the authors appreciate reviewer's detailed comments and constructive suggestions.

\section{ORCID ${ }^{\circledR}$ iDs}

Hwan Jung Lim - https://orcid.org/0000-0003-1914-0233

Seong Jun Park - https://orcid.org/0000-0003-1767-0900

\section{References}

1. Ingold, C. K.; Jessop, J. A. J. Chem. Soc. 1930, 713. doi:10.1039/JR9300000713

2. Johnson, A. W.; LaCount, R. B. J. Am. Chem. Soc. 1961, 83, 417. doi:10.1021/ja01463a040

3. Franzen, V.; Schmidt, H.-J.; Mertz, C. Chem. Ber. 1961, 94, 2942. doi:10.1002/cber.19610941117

4. Franzen, V.; Driesen, H.-E. Chem. Ber. 1963, 96, 1881. doi:10.1002/cber.19630960722

5. Corey, E. J.; Chaykovsky, M. J. Am. Chem. Soc. 1962, 84, 3782. doi:10.1021/ja00878a046

6. Corey, E. J.; Chaykovsky, M. J. Am. Chem. Soc. 1964, 86, 1640. doi:10.1021/ja01062a040

7. Corey, E. J.; Chaykovsky, M. J. Am. Chem. Soc. 1965, 87, 1353. doi:10.1021/ja01084a034
8. Nozaki, H.; Takaku, M.; Kondô, K. Tetrahedron 1966, 22, 2145. doi:10.1016/S0040-4020(01)82134-7

9. Ratts, K. W.; Yao, A. N. J. Org. Chem. 1966, 31, 1185. doi:10.1021/jo01342a047

10. Burtoloso, A. C. B.; Dias, R. M. P.; Leonarczyk, I. A. Eur. J. Org. Chem. 2013, 5005. doi:10.1002/ejoc.201300581

11. Moody, C. J.; Slawin, A. M. Z.; Taylor, R. J.; Williams, D. J. Tetrahedron Lett. 1988, 29, 6009. doi:10.1016/S0040-4039(00)82253-4

12. Moody, C. J.; Taylor, R. J. Tetrahedron 1990, 46, 6525. doi:10.1016/S0040-4020(01)96018-1

13. Li, A.-H.; Dai, L.-X.; Aggarwal, V. K. Chem. Rev. 1997, 97, 2341. doi:10.1021/cr960411r

14. Davoust, M.; Brière, J.-F.; Jaffrès, P.-A.; Metzner, P. J. Org. Chem. 2005, 70, 4166. doi:10.1021/jo0479260

15. Piccinini, A.; Kavanagh, S. A.; Connon, P. B.; Connon, S. J. Org. Lett. 2010, 12, 608. doi:10.1021/ol902816w

16. Aggarwal, V. K.; Hynd, G.; Picoul, W.; Vasse, J.-L. J. Am. Chem. Soc. 2002, 124, 9964. doi:10.1021/ja0272540

17. Chandrasekhar, S.; Narasihmulu, C.; Jagadeshwar, V.; Venkatram Reddy, K. Tetrahedron Lett. 2003, 44, 3629. doi:10.1016/S0040-4039(03)00732-9

18. Concellón, J. M.; Bardales, E. J. Org. Chem. 2003, 68, 9492. doi:10.1021/jo0349577

19. Paxton, R. J.; Taylor, R. J. K. Synlett 2007, 633. doi:10.1055/s-2007-967966

20. Edwards, M. G.; Paxton, R. J.; Pugh, D. S.; Whitwood, A. C.; Taylor, R. J. K. Synthesis 2008, 3279. doi:10.1055/s-0028-1083165

21. Robiette, R.; Marchan-Brynaert, J. Synlett 2008, 517. doi:10.1055/s-2008-1032080

22. Hartikka, A.; Arvidsson, P. I. J. Org. Chem. 2007, 72, 5874. doi:10.1021/jo070519e

23. Recent literature: Marsini, M. A.; Reeves, J. T.; Desrosiers, J.-N.; Herbage, M. A.; Savoie, J.; Li, Z.; Fandrick, K. R.; Sader, C. A.; McKibben, B.; Gao, D. A.; Cui, J.; Gonnella, N. C.; Lee, H.; Wei, X.; Roschangar, F.; Lu, B. Z.; Senanayake, C. H. Org. Lett. 2015, 17, 5614. doi:10.1021/acs.orglett.5b02838

24. Vaitla, J.; Bayer, A.; Hopmann, K. H. Angew. Chem., Int. Ed. 2017, 56, 4277. doi:10.1002/anie.201610520

25. Boyarskikh, V.; Nyong, A.; Rainier, J. D. Angew. Chem., Int. Ed. 2008, 47, 5374. doi:10.1002/anie.200801336

26. Soeta, T.; Ohgai, T.; Sakai, T.; Fujinami, S.; Ukaji, Y. Org. Lett. 2014, 16, 4854. doi:10.1021/ol502347n

27. Xu, X.; Li, C.; Tao, Z.; Pan, Y. Green Chem. 2017, 19, 1245. doi:10.1039/C6GC02681H

28. Enßle, M.; Buck, S.; Werz, R.; Maas, G. Beilstein J. Org. Chem. 2012, 8, 433. doi:10.3762/bjoc.8.49

29. Li, K.; Hu, J.; Liu, H.; Tong, X. Chem. Commun. 2012, 48, 2900. doi:10.1039/c2cc30242j

30. Liu, Y.-Y.; Yang, X.-H.; Huang, X.-C.; Wei, W.-T.; Song, R.-J.; Li, J.-H. J. Org. Chem. 2013, 78, 10421. doi:10.1021/jo401851m

31.Lu, L.-Q.; Cao, Y.-J.; Liu, X.-P.; An, J.; Yao, C.-J.; Ming, Z.-H.; Xiao, W.-J. J. Am. Chem. Soc. 2008, 130, 6946. doi:10.1021/ja800746q

32. Chen, J.-R.; Dong, W.-R.; Candy, M.; Pan, F.-F.; Jörres, M.; Bolm, C. J. Am. Chem. Soc. 2012, 134, 6924. doi:10.1021/ja301196x

33. Liu, Y.; Shao, X.; Zhang, P.; Lu, L.; Shen, Q. Org. Lett. 2015, 17, 2752. doi:10.1021/acs.orglett.5b01170

34. Zhu, J.; Liu, Y.; Shen, Q. Angew. Chem., Int. Ed. 2016, 55, 9050. doi:10.1002/anie.201603166 
35. Huang, X.; Goddard, R.; Maulide, N. Angew. Chem., Int. Ed. 2010, 49, 8979. doi:10.1002/anie.201002919

36. Huang, X.; Maulide, N. J. Am. Chem. Soc. 2011, 133, 8510. doi:10.1021/ja2031882

37. Huang, X.; Klimczyk, S.; Maulide, N. Synthesis 2012, 44, 175. doi:10.1055/s-0031-1289632

38. Huang, X.; Klimczyk, S.; Veiros, L. F.; Maulide, N. Chem. Sci. 2013, 4, 1105. doi:10.1039/c2sc21914j

39. Jamieson, A. G.; Russell, D.; Hamilton, A. D. Chem. Commun. 2012, 48, 3709. doi:10.1039/c2cc30295k

40. German, E. A.; Ross, J. E.; Knipe, P. C.; Don, M. F.; Thompson, S.; Hamilton, A. D. Angew. Chem., Int. Ed. 2015, 54, 2649. doi:10.1002/anie.201410290

41. Smith, A. B., III; Keenan, T. P.; Holcomb, R. C.; Sprengeler, P. A.; Guzman, M. C.; Wood, J. L.; Carroll, P. J.; Hirschmann, R. J. Am. Chem. Soc. 1992, 114, 10672. doi:10.1021/ja00052a093

42. Wyrembak, P. N.; Hamilton, A. D. J. Am. Chem. Soc. 2009, 131, 4566 doi:10.1021/ja809245t

43. Jouanne, M.; Voisin-Chiret, A. S.; Legay, R.; Coufourier, S.; Rault, S.; Santos, J. S. O. Eur. J. Org. Chem. 2016, 5686. doi:10.1002/ejoc.201600882

44. Kudo, N.; Perseghini, M.; Fu, G. C. Angew. Chem., Int. Ed. 2006, 45, 1282. doi:10.1002/anie.200503479

45. Rao, G. K.; Kumar, A.; Ahmed, J.; Singh, A. K. Chem. Commun. 2010, 46, 5954. doi:10.1039/c0cc01075h

46. Billingsley, K. L.; Anderson, K. W.; Buchwald, S. L. Angew. Chem., Int. Ed. 2006, 45, 3484. doi:10.1002/anie.200600493

47. Liu, C.; Ni, Q.; Hu, P.; Qiu, J. Org. Biomol. Chem. 2011, 9, 1054. doi:10.1039/C0OB00524J

48. Siddle, J. S.; Batsanov, A. S.; Bryce, M. R. Eur. J. Org. Chem. 2008, 2746. doi:10.1002/ejoc.200800018

49. Kitamura, Y.; Sako, S.; Tsutsui, A.; Moguchi, Y.; Maegawa, T.; Kitade, Y.; Sajiki, H. Adv. Synth. Catal. 2010, 352, 718. doi:10.1002/adsc.200900638

50. Yin, L.; Liebscher, J. Chem. Rev. 2007, 107, 133. doi:10.1021/cr0505674

51. Gildner, P. G.; Colacot, T. J. Organometallics 2015, 34, 5497. doi:10.1021/acs.organomet.5b00567

52. Ruiz-Castillo, P.; Buchwald, S. L. Chem. Rev. 2016, 116, 12564. doi:10.1021/acs.chemrev.6b00512

53. Clavé, G.; Pelissier, F.; Campidelli, S.; Grison, C. Green Chem. 2017, 19, 4093. doi:10.1039/C7GC01672G

54. Mabkhot, Y. N.; Kaal, N. A.; Alterary, S.; Al-Showiman, S. S.; Barakat, A.; Ghabbour, H. A.; Frey, W. Molecules 2015, $20,8712$. doi:10.3390/molecules20058712

55. Mabkhot, Y. N.; Alatibi, F.; El-Sayed, N. N. E.; Kheder, N. A.; Al-Showiman, S. S. Molecules 2016, 21, 1036. doi: $10.3390 /$ molecules 21081036

56. Acharya, A.; Parameshwarappa, G.; Saraiah, B.; Ila, H. J. Org. Chem. 2015, 80, 414. doi:10.1021/jo502429c

57. Sommen, G.; Comel, A.; Kirsch, G. Tetrahedron 2003, 59, 1557. doi:10.1016/S0040-4020(03)00054-1

58. Thomae, D.; Perspicace, E.; Henryon, D.; Xu, Z.; Schneider, S.; Hesse, S.; Kirsch, G.; Seck, P. Tetrahedron 2009, 65, 10453. doi:10.1016/j.tet.2009.10.021

59. Gaber, H. M.; Bagley, M. C. Eur. J. Chem. 2011, 2, 214. doi:10.5155/eurjchem.2.2.214-222.411

60. Apparao, S.; Ila, H.; Junjappa, H. J. Chem. Soc., Perkin Trans. 1 1983, 2837. doi:10.1039/p19830002837
61. Okada, E.; Masuda, R.; Hojo, M.; Imazaki, N.; Miya, H. Heterocycles 1992, 34, 103. doi:10.3987/COM-91-5897

62. Fadda, A. A.; Abdel-Latif, E.; El-Mekawy, R. E. Eur. J. Med. Chem. 2009, 44, 1250. doi:10.1016/j.ejmech.2008.09.006

63. Rudorf, W.-D. Z. Chem. 1979, 19, 100. doi:10.1002/zfch.19790190309

64. Fadda, A. A.; Abdel-Latif, E.; El-Mekawy, R. E. Pharmacol. Pharm. 2012, 3, 148. doi:10.4236/pp.2012.32022

65. Fadda, A. A.; Abdel-Latif, E.; El-Mekawy, R. E. Phosphorus, Sulfur Silicon Relat. Elem. 2008, 183, 1940. doi:10.1080/10426500701839536

66. Rateb, N. M. Phosphorus, Sulfur Silicon Relat. Elem. 2005, 180, 2361. doi:10.1080/104265090921083

67. Abu-Melha, S. Heterocycles 2016, 92, 1261. doi:10.3987/COM-16-13461

68. CCDC 1813136 (8ad) and CCDC 1813137 (8an) contain the supplementary crystallographic data for this paper. These data are provided free of charge by The Cambridge Crystallographic Centre.

69. Joule, J. A.; Mills, K. Heterocyclic Chemistry, 5th ed.; John Wiley \& Sons, Ltd.: Chichester, 2010; p 7. See for the structure of pyridine.

70. Joule, J. A.; Mills, K. Heterocyclic Chemistry, 5th ed.; John Wiley \& Sons, Ltd.: Chichester, 2010. p 120 and $p$ 146. See for the structures of alkylpyridines.

71. Joule, J. A.; Mills, K. Heterocyclic Chemistry, 5th ed.; John Wiley \& Sons, Ltd.: Chichester, 2010. p 10 and p 42. See for the structures of thiophene, furan, and oxidiazole.

72. Joule, J. A.; Mills, K. Heterocyclic Chemistry, 5th ed.; John Wiley \& Sons, Ltd.: Chichester; $\mathrm{p} 10$. See for the structure of imidazole.

73. Doering, W. v. E.; Hoffmann, A. K. J. Am. Chem. Soc. 1955, 77, 521. doi:10.1021/ja01608a003

74. Johnson, A. W.; Lacount, R. B. Tetrahedron 1960, 9, 130 doi:10.1016/0040-4020(60)80061-0

75. Sheppard, W. A. J. Am. Chem. Soc. 1962, 84, 3072 doi:10.1021/ja00875a007

76. Byrne, C. J.; Happer, D. A. R.; Hartshorn, M. P.; Powell, H. K. J. J. Chem. Soc., Perkin Trans. 2 1987, 1649. doi:10.1039/p29870001649

77. Shorter, J. Pure Appl. Chem. 1997, 69, 2497. doi:10.1351/pac199769122497

78. Hunter, G. A.; McNab, H. J. Chem. Soc., Perkin Trans. 1 1995, 1209 doi:10.1039/p19950001209

79. Fraser, R. R.; Mansour, T. S.; Savard, S. J. Org. Chem. 1985, 50, 3232. doi:10.1021/jo00217a050

80. Apparao, S.; lla, H.; Junjappa, H. J. Chem. Soc., Perkin Trans. 11983, 2837. doi:10.1039/p19830002837

81. Ila, H.; Junjappa, H. Chimia 2013, 67, 17. doi:10.2533/chimia.2013.17

82. Pan, L.; Bi, X.; Liu, Q. Chem. Soc. Rev. 2013, 42, 1251. doi:10.1039/C2CS35329F

83. Zhang, L.; Dong, J.; Xu, X.; Liu, Q. Chem. Rev. 2016, 116, 287. doi:10.1021/acs.chemrev.5b00360

84. Bernhardt, P. V.; Koch, R.; Moloney, D. W. J.; Shtaiwi, M.; Wentrup, C. J. Chem. Soc., Perkin Trans. 2 2002, 515. doi:10.1039/B109624A

85. Trost, B. M. J. Am. Chem. Soc. 1966, 88, 1587. doi:10.1021/ja00959a071

86. Stoffregen, S. A.; Heying, M.; Jenks, W. S. J. Am. Chem. Soc. 2007, 129, 15746. doi:10.1021/ja076351w

87. It cannot be ruled out that the pyridine moiety in $9 \mathrm{~b}$ could be act as a general base. 


\section{License and Terms}

This is an Open Access article under the terms of the Creative Commons Attribution License

(http://creativecommons.org/licenses/by/4.0), which permits unrestricted use, distribution, and reproduction in any medium, provided the original work is properly cited.

The license is subject to the Beilstein Journal of Organic Chemistry terms and conditions:

(https://www.beilstein-journals.org/bjoc)

The definitive version of this article is the electronic one which can be found at:

doi:10.3762/bjoc. 14.16 